Int. J. Electrochem. Sci., 14 (2019) $6902-6919$

\title{
Calotropis Procera Extract as Corrosion Inhibitor for Copper in Nitric Acidic Environment
}

\author{
Samar.Y. Al-Nami ${ }^{1}$, Abd El-Aziz S. Fouda ${ }^{2}$ \\ ${ }^{1}$ Chemistry Department, Science College for Girls, King Khalid University, Abha, KSA \\ ${ }^{2}$ Department of Chemistry, Faculty of Science, Mansoura University, Mansoura-35516, Egypt \\ *E-mail: asfouda@hotmail.com
}

doi:10.2064/2019.07.118

Received: 27 February 2019 / Accepted: 4 May 2019 / Published: 10 June 2019

The corrosion of $\mathrm{Cu}$ in $2.0 \mathrm{M} \mathrm{HNO}_{3}$ using Calotropis Procera $(\mathrm{CP})$ extract as save inhibitor has been conducted utilizing, AC impedance spectroscopy (EIS), Tafel polarization (PP), electrochemical frequency modulation (EFM) and weight loss (WL) tests. Polarization studies proved that, this extract plays as a mixed - kind inhibitor. Inhibition efficiency (IE) of this extract has been found to vary with concentration of $\mathrm{CP}$ extract and temperature. The thermodynamic parameters of $\mathrm{Cu}$ corrosion in $2.0 \mathrm{M}$ $\mathrm{HNO}_{3}$ were computed and discussed. The surface analysis of $\mathrm{Cu}$ was showed using several techniques. These analyses revealed that $\mathrm{CP}$ extract was adsorbed on the $\mathrm{Cu}$ surface, preventing the $\mathrm{Cu}$ surface from corrosion. Fourier transform infrared (FTIR) results showed that the mechanism of protection was by absorption process, through the functional group's present in the extract. All techniques gave parallel results.

Keywords: Calotropis Procera extract, Copper, Corrosion inhibition, HCl, Temkin isotherm

\section{FULL TEXT}

(C) 2019 The Authors. Published by ESG (www.electrochemsci.org). This article is an open access article distributed under the terms and conditions of the Creative Commons Attribution license (http://creativecommons.org/licenses/by/4.0/). 